\title{
Immunostimulatory effects of the phenolic compounds from lichens on nitric oxide and hydrogen peroxide production
}

\author{
Iracilda Z. Carlos, ${ }^{* 1}$ Camila B. A. Carli, ${ }^{1}$ Danielle C. G. Maia, ${ }^{1}$ Fernanda P. Benzatti, ${ }^{1}$ \\ Flavia C. M. Lopes, ${ }^{1}$ Fernanda M. Roese, ${ }^{2}$ Márcio Watanabe, ${ }^{2}$ Ana C. Micheletti, ${ }^{2}$ \\ Lourdes C. dos Santos, ${ }^{3}$ Wagner Vilegas, ${ }^{3}$ Neli K. Honda ${ }^{2}$
}

\author{
${ }^{1}$ Departament of Clinical Analysis, Faculdade de Ciências Farmacêuticas de Araraquara, \\ São Paulo State University, Post Office Box 502, Araraquara-SP 14801-902, Brazil \\ ${ }^{2}$ Departament of Chemistry, Universidade Federal do Mato Grosso do Sul, Campo Grande-MS, Brazil \\ ${ }^{3}$ Department of Organic Chemistry, Instituto de Química de Araraquara, São Paulo State University, \\ Post Office Box 355, Araraquara-SP 14801-970, Brazil
}

\begin{abstract}
RESUMO: "Efeito imunoestimulante de compostos fenólicos de líquens na produção de peróxido de hidrogênio e óxido nítrico". Os efeitos dos compostos isolados de líquens brasileiros e seus derivados na produção de $\mathrm{NO}$ e $\mathrm{H}_{2} \mathrm{O}_{2}$ foram estudados utilizando macrófagos murinos na tentativa de desvendar suas possíveis propriedades imunomodulatórias. A citotoxicidade dos compostos foi estudada utilizando o ensaio de MTT. A estimulação dos macrófagos foi avaliada através da determinação de $\mathrm{NO}$ (metodologia de Griess) e $\mathrm{H}_{2} \mathrm{O}_{2}$ (peroxidase de raíz forte/vermelho de fenol) no sobrenadante de culturas de macrófagos peritoneais de camundongos Swiss. Este estudo demonstrou atividade estimulante de alguns compostos fenólicos e seus derivados na produção de $\mathrm{NO}$ e $\mathrm{H}_{2} \mathrm{O}_{2}$. A relação estrutura atividade sugere inúmeras direções sintéticas para futuros melhoramentos da atividade imunológica.
\end{abstract}

Unitermos: líquens, peróxido de hidrogênio, óxido nítrico, macrófagos, compostos fenólicos.

\begin{abstract}
The effects of isolated compounds from Brazilian lichens and their derivatives on $\mathrm{H}_{2} \mathrm{O}_{2}$ and NO production were studied using murine macrophages as a part of an attempt to understand their possible immunomodulatory properties. The compound cytotoxicity was studied using MTT assay. Macrophage stimulation was evaluated by the determination of $\mathrm{NO}$ (Griess assay) and $\mathrm{H}_{2} \mathrm{O}_{2}$ (horseradish peroxidase/phenol red) in supernatants of peritoneal macrophage cultures of Swiss mice. This research demonstrated stimulatory activities of some phenolic compounds isolated from lichens and their derivatives on $\mathrm{H}_{2} \mathrm{O}_{2}$ and $\mathrm{NO}$ production. Structure-activity relationships suggest several synthetic directions for further improvement of immunological activity.
\end{abstract}

Keywords: lichens, hydrogen peroxide, nitric oxide, macrophages, phenolic compounds.

\section{INTRODUCTION}

Lichens are a large group of organisms formed by the symbiotic association of Chlorophyta or Cyanobacteria and a fungus. Along with Cyanobacteria they play an important role as pioneer organisms in colonizing rocks. Similar to higher plants, lichens were used as natural drugs. The organisms produce secondary metabolites and many of them are known for presenting biological and/or pharmacological activities (Fahselt, 1994).

The innate immune system is mainly mediated by macrophages, dendritic cells and NK cells (Schiller et al., 2006). Macrophages are major components of the mononuclear phagocyte system that consists of closely related cells of bone marrow origin, including blood monocytes, and tissue macrophages. In every stage of the immune response macrophages are involved and they can release many compounds such as hydrogen peroxide $\left(\mathrm{H}_{2} \mathrm{O}_{2}\right)$ and nitric oxide $(\mathrm{NO}) . \mathrm{H}_{2} \mathrm{O}_{2}$ is a lipid soluble molecule that crosses the cell membranes and it is scavenged by catalase and by glutathione peroxidase in biological systems (Schafer \& Buettner, 2001). Studies have suggested that $\mathrm{H}_{2} \mathrm{O}_{2}$ plays an important role in the functions of macrophages (Ramasarma, 1990). It also has many different functions in the human body, acting as a signaling molecule and a cytotoxic agent in the defense system (Abe \& Bradford, 1999). NO has cytotoxic properties and it is produced during host defense against invasive organisms and immunologic reactions. It is also involved in many physiologic processes of mammals, including neurotransmition, blood pressure control and inflammation (Costa et al., 2003; Garcia \& Stein, 2006). 
Many polysaccharides obtained from fungi are considered modifiers of the biological response and have been shown to modulate immune response. Compounds isolated from fungi had been shown to enhance immune response through the up-regulation of nitric oxide from peritoneal macrophages acting as an effective immunomodulator and an anti-tumoral agent. (Suzuki et al., 1985; Kim et al., 2004; Santos et al., 2004; Gao et al., 2005; Zheng et al., 2005). Since the symbiotic association of algae with fungus forms lichens and there are just few works about the pharmacological properties of lichens, in this research we decided to study pure compounds isolated from Brazilian lichens and their derivatives. The effects of phenolic compounds and their derivatives on $\mathrm{H}_{2} \mathrm{O}_{2}$ and NO production were studied using murine macrophages as a part of an attempt to understand their possible immunomodulatory properties.

\section{MATERIAL E MÉTODOS}

\section{Lichens}

The lichen Parmotrema dilatatum (Vain.) Hale Parmeliaceae was collected in Mato Grosso do Sul, state, Brazil; Ramalina sp. Ramalinaceae and Parmotrema lichexanthonicum Eliasaro \& Adler Parmeliaceae were obtained from the shops of decoration products. The identification was conduced by Profa. Dra. Mariana Fleig from UFRGS and Prof. Dr. Marcelo P. Marcelli from the Instituto de Botânica de São Paulo. A voucher specimen of each species is kept in our laboratory for future reference.

\section{Extraction and isolation of compounds}

P. dilatatum, P. lichexanthonicum and Ramalina sp. were extracted with chloroform and acetone exaustively. The extracts were concentrated in vacuo. The extract obtained from each lichen was fractionated on Si-gel CC and eluted with hexane-chloroform mixtures in crescent polarity to give lichexanthone [1] (P. lichexanthonicum). From the acetone extract of the lichens $P$. dilatatum and Ramalina sp. were isolated protocetraric acid [2] and norstitic acid [3], respectively. The purification of these compounds was conduced by treatment with small volume of acetone in an ice bath. The degree of purity for all lichen compounds was $>95 \%$ as determined by TLC, HPLC and NMR analysis. The compounds [1], [2] and [3] and the derivatives obtained from compounds [2] and [3] were studied in this research.

\section{Derivatives}

Compounds I-IX and $\mathbf{X}$-XI were obtained through reactions with alcohols with the protocetraric acid [2] and norstitic acid [3], respectively. The purification of these compounds was conduced by sucessive treatments with acetone in an ice bath. Methyl protocetrarate (XII): protocetraric acid [2] was treated with $\mathrm{CH}_{3} \mathrm{I}$ and $\mathrm{K}_{2} \mathrm{CO}_{3}$ in DMF (Garner \& Park, 1992). Physodalic acid (XIII); protocetraric acid [2] was solubilized in DMF and acetylated by glacial acetic acid (Elix \& Engkaninan, 1975). Conprotocetraric acid (XIV): Protocetraric acid [2] was reduced by sodium borohydride $\left(\mathrm{NaBH}_{4}\right)$ (Wolfrom \& Thomson, 1963). The structures were confirmed by 1D and 2D NMR spectra and checked with literature data (Huneck \& Yoshimura, 1996).

\section{Animals}

Swiss mice (six-eight weeks old, weighting 18 to $25 \mathrm{~g}$ ) were maintained in a polycarbonate box (at $23 \pm 1$ ${ }^{\circ} \mathrm{C}, 55 \pm 5 \%$ humidity, $10-18$ circulations/h and a $12 \mathrm{~h}$ light/ dark cycle), with water and food available ad libitum. At least five animals were used for each experiment.

\section{Peritoneal exsudate cells}

Thioglycollate-elicited peritoneal exsudate cells (PEC) were harvested from Swiss mice using $5.0 \mathrm{~mL}$ of sterile phosphate-buffered saline (PBS), $\mathrm{pH}$ 7.4. The cells were washed twice by centrifugation at $200 \mathrm{xg}$ for $5 \mathrm{~min}$ at $4{ }^{\circ} \mathrm{C}$ and re-suspended in appropriate medium for each test.

\section{MTT assay}

$\operatorname{PEC}\left(5 \times 10^{6}\right.$ cells $\left./ \mathrm{mL}\right)$ were resuspended in RPMI1640 containing $5 \%$ heat inactivated fetal bovine serum (FBS), $100 \mathrm{IU} / \mathrm{mL}$ penicillin, $100 \mu \mathrm{g} / \mathrm{mL}$ streptomycin and $50 \mathrm{mM} 2$-mercaptoethanol. The suspension $(100 \mu \mathrm{L})$ and the test material $(100 \mu \mathrm{L})$ were added to each well of a ninety six-well tissue culture plate and the plates were incubated for $24 \mathrm{~h}$. MTT solution was added $(100 \mu \mathrm{L})$ and the plate was incubated for $3 \mathrm{~h}$ at $37 \mathrm{oC}$ with $5 \% \mathrm{CO}_{2}$. Absorbance was read in a UV/Vis spectrophotometer at a wave length of $540 \mathrm{~nm}$, with a reference filter of 620 $\mathrm{nm}$. The culture medium and cells alone were used as control, representing $100 \%$ viability of the macrophages (Mosmann, 1983).

\section{$\mathrm{H}_{2} \mathrm{O}_{2}$ production}

PEC $\left(2 \mathrm{x} 10^{6}\right.$ cells $\left./ \mathrm{mL}\right)$ were cultivated as described above and suspended in a solution containing $140 \mathrm{mmol} \mathrm{NaCl}, 10 \mathrm{mmol}$ potassium phosphate buffer, $\mathrm{pH}$ 7.0, $5.5 \mathrm{mmol}$ dextrose, $0.56 \mathrm{mmol}$ phenol red, and 0.01 $\mathrm{mg} / \mathrm{mL}$ type II horseradish peroxidase. Next, $100 \mu \mathrm{l}$ of this suspension was added to each of the wells of a ninety six-well flat-bottom tissue culture plate and exposed to 50 $\mu \mathrm{L}$ of the compounds. Phorbol myristate acetate (PMA) solution in phosphate buffer was used as a positive control. The cells were incubated for $1 \mathrm{~h}$ at $37{ }^{\circ} \mathrm{C}$ in a mixture of $95 \%$ air and $5 \% \mathrm{CO}_{2}$. The reaction was stopped with $10 \mu \mathrm{L}$ 
of $4 \mathrm{~N} \mathrm{NaOH}$ and the samples were read at $620 \mathrm{~nm}$ with a Multiskan Ascent ELISA reader against a blank containing phenol red solution and $4 \mathrm{~N} \mathrm{NaOH}$. The results were expressed as nanomoles of $\mathrm{H}_{2} \mathrm{O}_{2} / 2 \times 10^{6}$ peritoneal cells, from a standard curve established in each test consisting of known molar concentrations of $\mathrm{H}_{2} \mathrm{O}_{2}$ in buffered phenol red. At least four experiments were used for the test (Pick \& Keisari, 1980; Pick \& Mizel, 1981).

\section{NO production}

PEC were harvested from Swiss mice using sterile PBS, pH 7.4. The cells were washed twice by centrifugation at $200 \mathrm{xg}$ for $5 \mathrm{~min}$ and resuspended in complete RPMI1640 culture medium containing $100 \mathrm{U} / \mathrm{mL}$ penicillin, $100 \mathrm{mg} / \mathrm{mL}$ streptomycin, $5 \times 10^{-2} \mathrm{M}$ mercaptoethanol and $5 \%$ inactivated fetal calf serum. The medium of this composition was denoted complete RPMI-1640 (RPMI1640-C) and was used for cell counts in a Neubauer chamber (Boeco, Germany) and the cell suspension was adjusted to a concentration of $5 \times 10^{6}$ cells $/ \mathrm{mL}$. A $100 \mu \mathrm{L}$ of this suspension was added to each well of a ninety six well tissue culture plate with different tested compounds. Escherichia coli O26:B6 lipopolysaccharide (LPS) was used as a positive control. The plates were then incubated for $24 \mathrm{~h}$ at $37^{\circ} \mathrm{C}$ under, $7.5 \% \mathrm{CO}_{2}$. The nitrite concentrations were indirectly measured by a quantitative colorimetric assay using Griess reagent system: $50.0 \mu \mathrm{L}$ aliquots of supernatant were added to $50.0 \mu \mathrm{L}$ of Griess reagent ( $1 \%$ sulphanilamide, $0.1 \%$ naphthylethylenediamine and 3\% $\mathrm{H}_{3} \mathrm{PO}_{4}$ ), incubated at room-temperature for $10 \mathrm{~min}$, and the absorbance was measured at $540 \mathrm{~nm}$ in an Elisa microplate reader (Multiskan Ascent Labsystems). Supernatants from quadruplicate cultures were assayed in four experiments and reported as $\mu$ mols $\mathrm{NO} / 5 \mathrm{x} 10^{5}$ cells as calibrated against solutions of known $\mathrm{NaNO}_{2}$ concentration. (Green et al., 1982).

\section{Statistical Analysis}

Data were expressed as mean \pm standard deviation, and the Dunnet t-test (Microcal Origin 5.0) was used to determine the significance of the differences between the negative control and tested compounds.

\section{RESULTS AND DISCUSSION}

Nowadays, compounds isolated from botanical sources as mushrooms, algae, lichens and higher plants have attracted a great deal of attention in the biomedical area because of their broad spectrum of therapeutic properties and relatively low toxicity (Schepetkin \& Quinn, 2006).

The cytotoxic effect of the compounds tested in peritoneal macrophages was assessed by the MTT assay as previously described (Table 1, Figure 1) (Mosmann, 1983). The tested concentration was show in the Table 1. It was used the concentration which the viability was higher or the same of $50 \%$.

Table 1. Tested concentrations used in the assays.

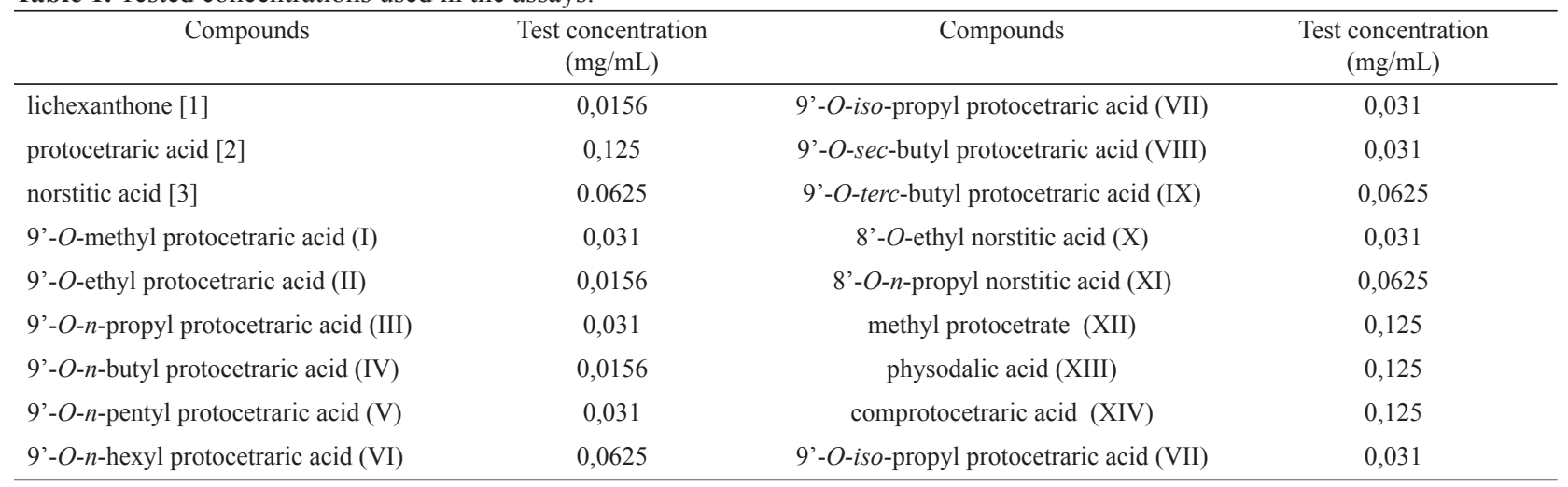

Initial stage of the immune response macrophages is involved and they can release many mediators such as hydrogen peroxide $\left(\mathrm{H}_{2} \mathrm{O}_{2}\right)$ and nitric oxide $(\mathrm{NO})$. The killing of intracellular and extracellular pathogens by phagocytes is due in part to the production of reactive oxygen intermediate (ROIs). The $\mathrm{H}_{2} \mathrm{O}_{2}$ is responsible for killing internalized bacteria in phagocytosis. The NO has central functions in innate immunity and regulation of immune functions. It has important roles in inhibiting tumor cell adhesion, arresting the growth of tumor cells and contributing to the control of microbial pathogens (Maragos et al., 1993; Kong et al., 1996; Rajan et al., 1996; Bogdan et al., 2000; Carlos et al., 2003; Chakravortty \& Hensel, 2003). The antimicrobial and cytotoxic actions of NO are enhanced by other macrophage products such as $\mathrm{H}_{2} \mathrm{O}_{2}$ and superoxide (MacMicking et al.,
1997).

Our results showed that the compounds I, V, VIII and IX induced a small production of $\mathrm{H}_{2} \mathrm{O}_{2}$ (Figure 2), however the compound VI showed a high production of this mediator when it was added to the cell culture (approximately $18 \mathrm{nmols} / 2 \mathrm{x}$ $10^{5}$ cells). Analyzing the production of NO (Figure 3), it was observed that compounds VIII, IX and XIII induced a small production of this mediator when compared with the negative control, with IX presenting statistical difference, $p<0.05$. The compounds I, II and $\mathbf{V}$ were more representative in the production of this mediator; all of them showed a significative liberation of NO, approximately 23,90 and $13 \mu \mathrm{mols} / 5 \times 10^{5}$ cells, respectively $(\mathrm{p}<0.001)$. It is important to notice that compound $\mathbf{V}$ was also derivatived from compound II (Santos et al., 2004). 


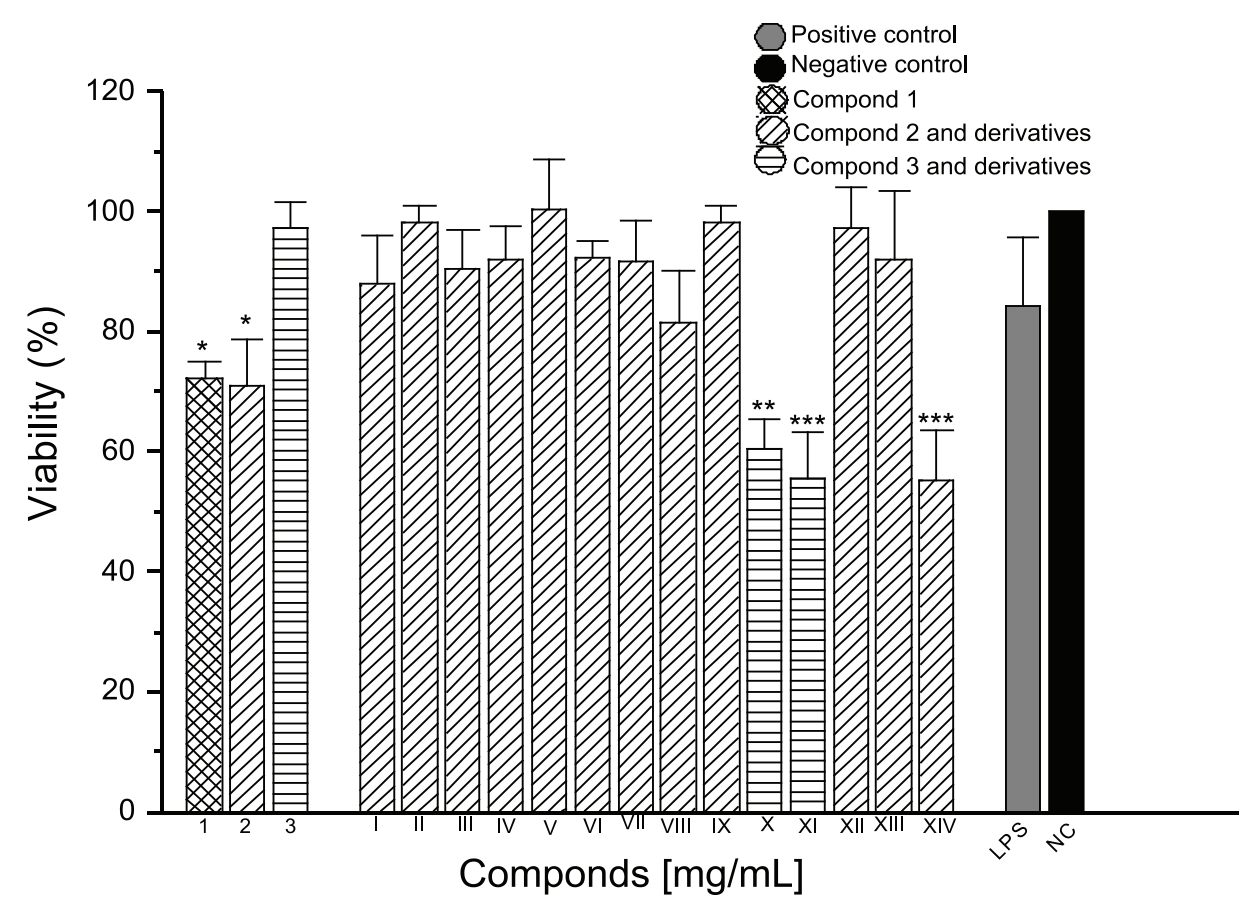

Figure 1. Determination of the viability in macrophages peritoneal culture of Swiss mice in the presence of phenolic substances isolated from Brazilian lichens and their modification structural products. $* \mathrm{p}<0.05, * * \mathrm{p}<0.01, * * * \mathrm{p}<0.001$

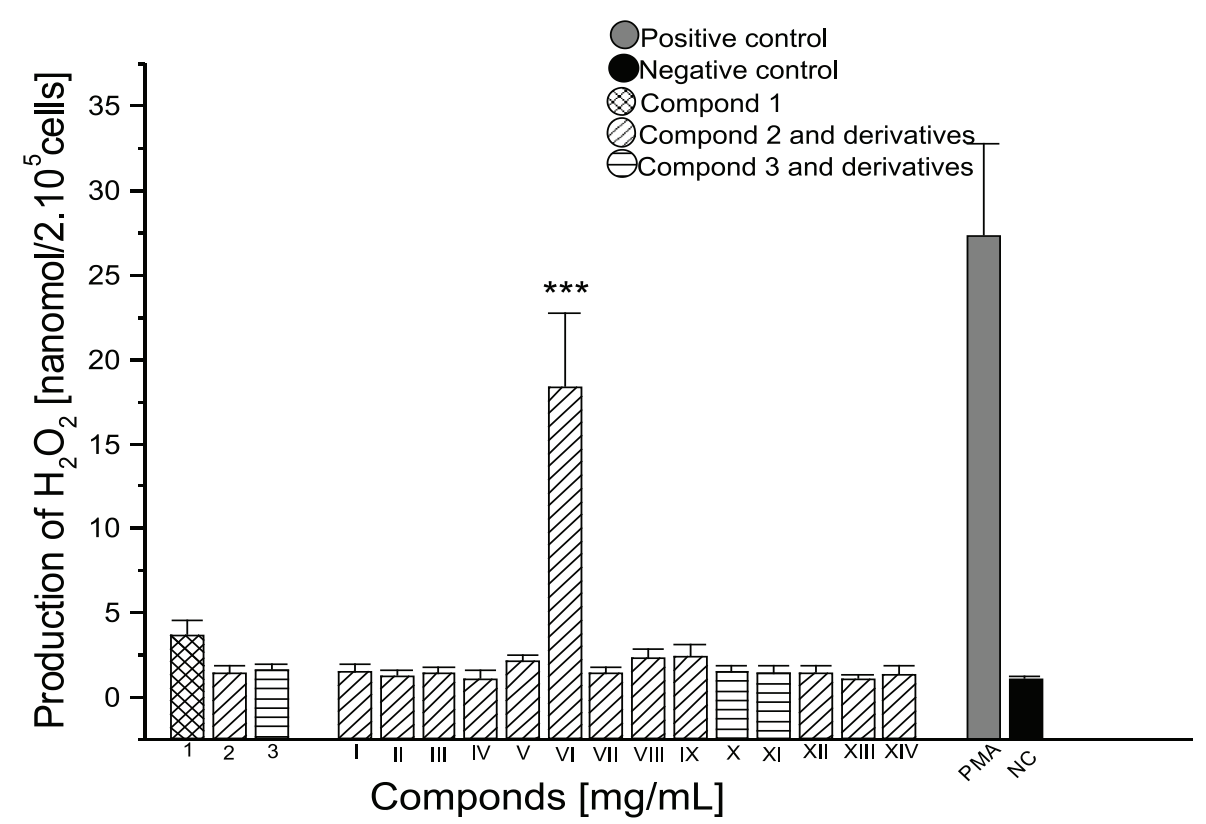

Figure 2. Determination of $\mathrm{H}_{2} \mathrm{O}_{2}$ in macrophages peritoneal culture of Swiss mice in the presence of presence of phenolic substances isolated from Brazilian lichens and their modification structural products. ***p $<0.001$ 


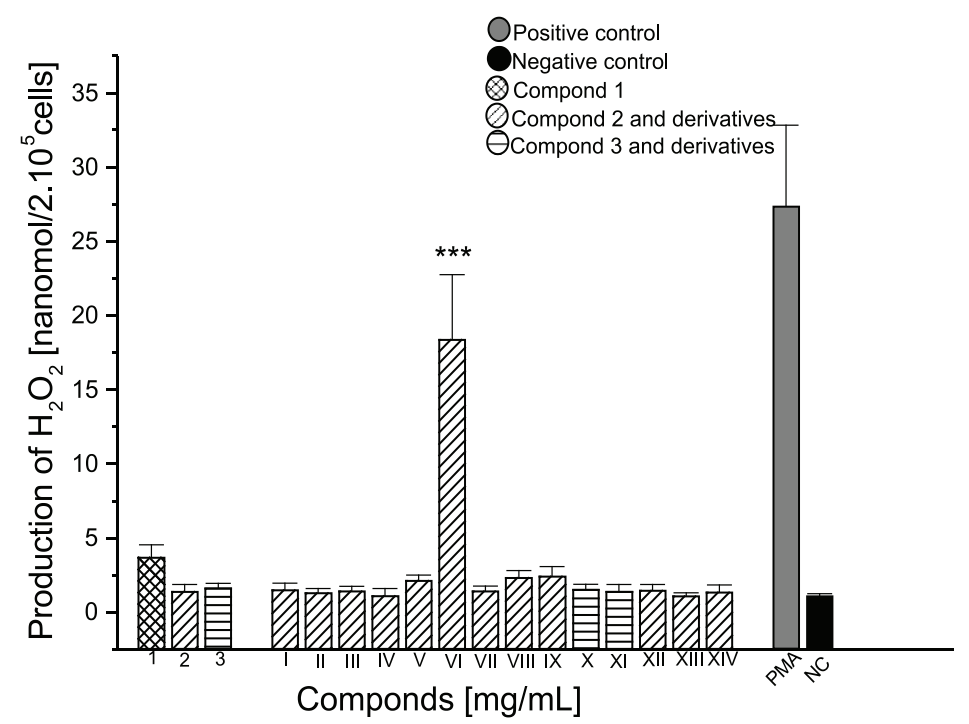

Figure 3. Determination of NO in macrophages peritoneal culture of Swiss mice in the presence of presence of phenolic substances isolated from Brazilian lichens and their modification structural products. ${ }^{*} \mathrm{p}<0.05,{ }^{* * *} \mathrm{p}<0.001$

The compound [2] (protocetraric acid) presents three functions: alcohol, acid and aldehyde that were modified in this study and showed high production of NO. When the aldehyde function was modified for alcohol (XII) or the acid function was modified for ester (XIV), $\mathrm{H}_{2} \mathrm{O}_{2}$ and $\mathrm{NO}$ production was not observed. In contrast, when the alcohol function was substituted for ether, induced a small NO production, exception compound $\mathbf{V}$ demonstrated a higher release of this mediator. However, a small production of $\mathrm{H}_{2} \mathrm{O}_{2}$ induced by compounds $\mathbf{V}, \mathbf{V I I I}$ and $\mathbf{I X}$ and a high liberation caused by compound VI can be explained due to higher liphophylic of the molecule because of the presence of the $n$-hexyl radical in the position 9'. The norstitic acid [3] and their derivatives ( $\mathbf{X}$ and $\mathbf{X I}$ ) did not induced the production of $\mathrm{H}_{2} \mathrm{O}_{2}$ and $\mathrm{NO}$ by the macrophages. The lichexanthone [1] showed significative production of $\mathrm{NO}$ and its derivatives must be subsequently studied.<smiles>COc1cc(C)c2c(=O)c3c(O)cc(OC)cc3oc2c1</smiles>

[1]<smiles>[R]OCc1c(O)c(C(=O)O)c(C)c2c1OC(=O)c1c(C)cc(O)c(C)c1O2</smiles>

$\mathbf{I} \mathrm{R}=\mathrm{CH}_{3}$

II R $=\mathrm{CH}_{2} \mathrm{CH}_{3}$

III R $=\mathrm{CH}_{2} \mathrm{CH}_{2} \mathrm{CH}_{3}$

IV R $=\mathrm{CH}_{2}\left(\mathrm{CH}_{2}\right)_{2} \mathrm{CH}_{3}$

$\mathbf{V ~ R}=\mathrm{CH}_{2}\left(\mathrm{CH}_{2}\right)_{3} \mathrm{CH}_{3}$

VI R $=\mathrm{CH}_{2}\left(\mathrm{CH}_{2}\right)_{4} \mathrm{CH}_{3}$

VII R $=\mathrm{CH}\left(\mathrm{CH}_{3}\right)_{2}$

VIII R $=\mathrm{CH}\left(\mathrm{CH}_{3}\right) \mathrm{CH}_{2} \mathrm{CH}_{3}$

IX R $=\mathrm{C}_{(}\left(\mathrm{CH}_{3}\right)_{3}$<smiles>Cc1cc(O)c(C)c2c1Oc1c(CO)c(O)c(C(=O)O)c(C)c1OC2=O</smiles><smiles>Cc1cc(O)c(C)c2c1Oc1c(C)c(CO)c(O)c(CO)c1OC2=O</smiles>

[2]<smiles>CCOC1(O)OC(=O)c2c(O)c(C)c3c(c21)OC(=O)c1c(C)cc(O)c(CO)c1O3</smiles>

$\mathrm{X}$<smiles>COC(C)=O</smiles>

XIII<smiles>Cc1cc(O)c(C)c2c1C(=O)Oc1c(C)c(O)c3c(c1O2)C(O)(O)OC3=O</smiles>

[3]<smiles>CCCOC1(O)OC(=O)c2c(O)c(C)c3c(c21)OC(=O)c1c(C)cc(O)c(C)c1O3</smiles>

XI<smiles>CC(=O)c1c(C)c(O)c(CO)c2oc3c(CO)c(O)cc(C)c3c(=O)c12</smiles>

XIV 
This research demonstrated stimulatory activities of some phenolic compounds isolated from lichens on $\mathrm{H}_{2} \mathrm{O}_{2}$ and NO production by murine macrophages, suggesting that these compounds are activators of macrophages. The induction of $\mathrm{H}_{2} \mathrm{O}_{2}$ and $\mathrm{NO}$ may contribute in the immunoprevention of cancer and infecctious diseases.

In conclusion, structure-activity relationships suggest several synthetic directions for further improvement of immunological activity. Protocetraric acid derivatives appear to be promising as immunostimulating agents.

\section{REFERENCES}

Abe J, Bradford BC 1999. Fyn and JAK2 mediate ras activation by reactive oxygen species. J Biol Chem 274: 2100321010.

Bogdan C, Rollinghoff M, Diefenbach A 2000. Reactive oxygen and reactive nitrogen intermediates in innate and specific immunity. Curr Opin Immunol 12: 64-76.

Carlos IZ, Sgarbi DBG, Santos GC, Placeres MCP 2003. Sporothrix schenckii lipid inhibits macrophage phagocytosis: involvement of nitric oxide and tumor necrosis factor- $\alpha$. Scand J Immunol 57: 214-220.

Chakravortty D, Hensel M 2003. Inducible nitric oxide synthase and control of intracellular bacterial pathogens. Microbes Infect 5: 621-627.

Costa MT, Fabeni RC, Aptekmann KP, Machado RR 2003. Diferentes papéis do óxido nítrico com ênfase nas neoplasias. Cienc Rural 33: 967-974.

Elix JA, Engkaninan U 1975. The structure of galbinic acid. A depsidone from the lichen Usnea undulata. Aust J Chem 28: 1793-1797.

Fahselt D 1994. Secondary biochemistry of lichens. Symbiosis 16: 117-165.

Gao Y, Gao H, Chan E, Tang W, Xu A, Yang H, Huang M, Lan J, Li X, Duan W, Xu C, Zhou S 2005. Antitumor activity and underlying mechanisms of ganopoly, the refined polysaccharides extracted from Ganoderma Lucidum, in Mice. Immunol Invest 34: 171-198.

Garcia X, Stein F 2006. Nitric oxide. Semin Pediatr Infect Dis 17: $55-57$

Garner P, Park JM 1992. 1,1-Dimethylethyl (S)- or (R)-4-formyl2,2-Dimethyl-3-oxazolidinecarboxylate: a useful serinal derivative. Org Synth 70: 18-28.

Green LC, Wagner DA, Glogowski J, Skipper PL, Wishnok JS, Tannenbaum SR 1982. Analysis of nitrate, nitrite, and $[15 \mathrm{~N}]$ nitrate in biological fluids. Anal Biochem 126: 131-138.

Huneck S, Yoshimura I 1996. Identification of Lichen Substances. Berlin: Springer-Verlag.

Kim GY, Choi GS, Lee SH, Park YM 2004. Acidic polysaccharide isolated from Phellinus linteus enhances through the upregulation of nitric oxide and tumor necrosis factor- $\alpha$ from peritoneal macrophages. $J$ Ethnopharmacol 95: 69-76.

Kong L, Dunn GD, Keefer LK, Korthuis RJ 1996. Nitric oxide reduces tumor cell adhesion to isolated rat postcapillary venules. Clin Exp Metastasis 14: 335-343.

MacMicking JD, Xie QW, Nathan C 1997. Nitric oxide and macrophage function. Annu Rev Immunol 15: 323-350.

Maragos CM, Wang JM, Hrabie JA, Oppenheim JJ, Keefer LK 1993. Nitric oxide/nucleophile complexes inhibit the in vitro proliferation of A375 melanoma cells via nitric oxide release. Cancer Res 53: 564-568.

Mosmann T 1983. Rapid colorimetric assay for cellular growth and survival: application to proliferation and cytotoxicity assays. J Immunol Methods 65: 55-63.

Pick E, Keisari Y 1980. A simple colorimetric method for the measurement of hydrogen peroxide produced by cells in culture. J Immunol Methods 38: 161-170.

Pick E, Mizel D J 1981. Rapid microassays for the measurement of superoxide and hydrogen peroxide production by macrophages in culture using an automatic enzyme immunoassay reader. J Immunol Methods 46: 211-226.

Rajan TV, Porte P, Yates JA, Keefer L, Shultz LD 1996. Role of nitric oxide in host defense against an extracellular, metazoan parasite. Infect Immun 64: 3351-3353.

Ramasarma T 1990. H2O2 has a role in cellular regulation. Indian J Biochem Bio 27: 269-74.

Santos LC, Honda NK, Carlos IZ, Vilegas W 2004. Intermediate reactive oxygen and nitrogen from macrophages induced by Brazilian lichens. Fitoterapia 75: 473-479.

Schafer FQ, Buettner GR 2001. Redox state of the cell as viewed though the glutathione disulfide/glutathione couple. Free Radical Biol Med 30: 1191-1212.

Schepetkin IA, Quinn MT 2006. Botanical polysaccharides: Macrophage immunomodulation and therapeutic potential. Int Immunopharmacol 6: 317-333.

Schiller M, Metze D, Luger TA, Grabbe S, Gunzer M 2006. Immune response modifiers-mode of action. Exp Dermatol 15: 331-341.

Suzuki I, Itani T, Ohno N, Oikawa S, Sato K, Miyazaki T, Yadomae T 1985. Effect of a polysaccharide fraction from Grifola frondosa on immune response in mice. $J$ Pharmacobio-Dynam 8: 217-226.

Wolfrom ML, Thompson A 1963. Reduction products-reduction with sodium borohydrate. In: Whistler RL, Wolfrom ML Methods in Carbohydrate Chemistry. New York: Academic Press, p. 65-68.

Zheng R, Jie S, Hanchuan D, Moucheng W 2005. Characterization and immunomodulating activities of olysaccharide from Lentinus edodes. Int Immunopharmacol 5: 811-820. 